\title{
BMJ Open Progressive resistance training in Parkinson's disease: a systematic review and meta-analysis
}

\author{
Mikhail Saltychev, ${ }^{1}$ Esa Bärlund, ${ }^{2}$ Jaana Paltamaa, ${ }^{3}$ Niina Katajapuu, ${ }^{4}$ Katri Laimi ${ }^{1}$
}

To cite: Saltychev M, Bärlund E, Paltamaa J, et al. Progressive resistance training in Parkinson's disease: a systematic review and meta-analysis. BMJ Open 2016;6:e008756.

doi:10.1136/bmjopen-2015008756

- Prepublication history and additional material is available. To view please visit the journal (http://dx.doi.org/ 10.1136/bmjopen-2015008756).

Received 13 May 2015 Revised 23 October 2015 Accepted 26 October 2015

CrossMark

For numbered affiliations see end of article.

Correspondence to Dr Mikhail Saltychev; mikhail.saltychev@gmail.com

\section{ABSTRACT}

Objectives: To investigate if there is evidence on effectiveness of progressive resistance training in rehabilitation of Parkinson disease.

Design: Systematic review and meta-analysis. Data sources: Central, Medline, Embase, Cinahl, Web of Science, Pedro until May 2014. Randomised controlled or controlled clinical trials. The methodological quality of studies was assessed according to the Cochrane Collaboration's domain-based evaluation framework. Data synthesis: random effects meta-analysis with test for heterogeneity using the $\mathrm{I}^{2}$ and pooled estimate as the raw mean difference.

Participants: Adults with primary/idiopathic Parkinson's disease of any severity, excluding other concurrent neurological condition.

Interventions: Progressive resistance training defined as training consisting of a small number of repetitions until fatigue, allowing sufficient rest between exercises for recovery, and increasing the resistance as the ability to generate force improves.

Comparison: Progressive resistance training versus no treatment, placebo or other treatment in randomised controlled or controlled clinical trials.

Primary and secondary outcome measures: Any outcome.

Results: Of 516 records, 12 were considered relevant. Nine of them had low risk of bias. All studies were randomised controlled trials conducted on small samples with none or 1 month follow-up after the end of intervention. Of them, six were included in quantitative analysis. Pooled effect sizes of metaanalyses on fast and comfortable walking speed, the 6 min walking test, Timed Up and Go test and maximal oxygen consumption were below the level of minimal clinical significance.

Conclusions: There is so far no evidence on the superiority of progressive resistance training compared with other physical training to support the use of this technique in rehabilitation of Parkinson's disease.

Systematic review registration number: PROSPERO 2014:CRD42014009844.

\section{INTRODUCTION}

Principles of progressive resistance training (PRT) have remained essentially unchanged since 1945-1949, when US Army physician

\section{Strengths and limitations of this study}

- Search in six major databases.

- More relevant studies identified compared to previous meta-analyses.

- Reviewing process followed recommendations by Cochrane Collaboration.

- Owing to the uncertain definition of progressive resistance training, it is possible that some relevant studies remained undetected.

Captain Thomas L. Delorme introduced this technique as an efficient way to rehabilitate soldiers. ${ }^{1}{ }^{2}$ For 70 years, PRT has been widely used in rehabilitation of young and physically active people. During the past two decades, use of PRT has also been studied among people with chronic diseases and disabilities $^{3} 4$ such as hypertension, chronic obstructive pulmonary disorders, chronic low back and neck pain, osteoarthritis, cerebral palsy, stroke and diabetes. In these conditions, PRT may reduce pain, and improve muscle strength and the level of physical activity without significant side effects. ${ }^{3}$

The data on the effectiveness of PRT in the rehabilitation of people with Parkinson's disease are scarce. The conclusions of recent reviews on the topic show inconsistency of inferences. In a recent systematic review by Brienesse $e t a \check{p}$ of five randomised controlled trials (RCT), PRT was found to have a positive effect on muscle strength, mobility, endurance, fat-free mass and performance in functional tasks. Another recent systematic review by Lima et at of four controlled trials suggested that PRT could be effective in increasing walking capacity in Parkinson's disease. A narrative review by David et $a l^{7}$ reported a favourable effect of PRT on muscle strength and function and non-motor symptoms of Parkinson's disease. Also, a narrative review by Falvo et $a l$ emphasised the lack of robust data on the topic. While Lima et $a l$ and David et al ended up with a strong 
conclusion that there is evidence that progressive resistance training should be implemented in Parkinson's disease rehabilitation, the conclusions of Brienesse et al and Falvo et al indicated more cautiously that data are insufficient to make robust recommendations and further research is needed.

The purpose of this study was to evaluate the evidence on the effectiveness of PRT in the rehabilitation of people with Parkinson's disease, and to make concrete recommendations for clinical practice.

\section{METHODS}

\section{Data sources and searches}

Criteria for considering studies for this review were based on the PICO (Population, Intervention, Comparison, and Outcome) framework as follows:

- Patients: Adults with primary/idiopathic Parkinson's disease of any severity, excluding any other concurrent neurological condition.

- Intervention: Progressive resistance training defined as training which (A) consists of a small number of repetitions until fatigue, (B) allows sufficient rest between exercises for recovery and $(\mathrm{C})$ increases the resistance as patient's ability to generate force improves. ${ }^{3}$
- Comparison: Progressive resistance training versus no treatment, placebo or other treatment in randomised controlled or controlled clinical trials.

- Outcome: Any outcome.

Cochrane Controlled Trials Register (CENTRAL), MEDLINE (via PubMed), EMBASE, CINAHL, Web of Science and Physiotherapy Evidence (Pedro) databases were searched in May 2014 with no restrictions by date or language. The search clauses are presented in online supplementary file 1 . In order to avoid missing relevant studies, the use of limits was restricted and further selection was conducted manually. The references of identified articles and reviews were also checked for relevancy.

\section{Study selection}

Two independent reviewers (EB and MS) screened the titles and abstracts of articles, assessed the full texts of potentially relevant studies, and rated the methodological quality of included trials (figure 1).

Disagreements between reviewers were resolved by consensus or by the third reviewer (JP). The more detailed description of the exclusion process is available on request from the corresponding author.

\section{Data extraction and quality assessment}

Data needed for meta-analysis were extracted from the included trials using a standardised form based on

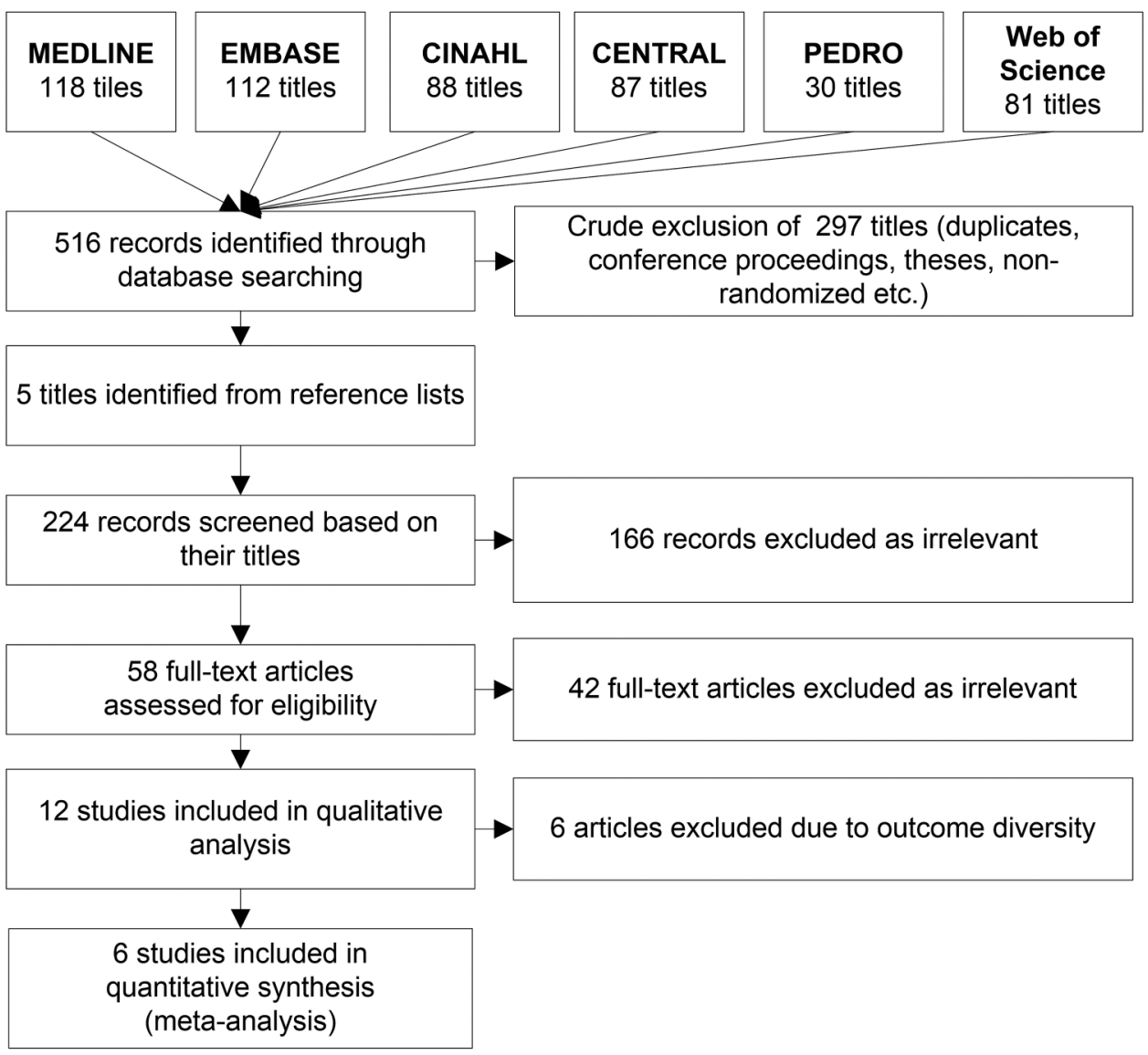

Figure 1 Flow chart of reviewing process. 
recommendations by the Cochrane Handbook for Systematic Reviews of Interventions V.5.1.0, part 7.6. ${ }^{9}$ If a study was reported in more than one publication, the information from multiple reports was collated by extracting data from each report separately and then combining the information of all data collection forms.

The methodological quality was assessed according to the Cochrane Collaboration's domain-based evaluation framework. ${ }^{10}$ Main domains were assessed in the following sequence: (1) selection bias (randomised sequence generation and allocation concealment); (2) performance bias (blinding of participants and personnel); (3) detection bias (blinding of outcome assessment); (4) attrition bias (incomplete outcome data, eg, due to dropouts); (5) reporting bias (selective reporting); (6) other sources of bias. The scores for each bias domain and the final score of risk of systematic bias were graded as low, high or unclear risk.

\section{Data synthesis and analysis}

We used a random effects meta-analysis to quantify the pooled effect size of included studies as a more natural choice than fixed effects in the context of multiple clinical trials conducted in diverse settings. In addition, test for heterogeneity supported this choice. The test for heterogeneity was conducted using the $\mathrm{I}^{2}$ statistic describing the percentage of variation across studies originating more from heterogeneity than from chance. We calculated the non-standardised means of difference in change of means for each study and for the pooled study sample. When the SD of difference of changes of groups' means was not reported, the coefficient of correlation between prevariance and postvariance was set at 0.6 . The potential publication bias was evaluated by Egger's test for asymmetry of the funnel plot (test for the $\mathrm{Y}$ intercept $=0$ from the linear regression of normalised effect estimate against precision), where the trim-and-fill method was used to impute studies into a funnel plot to correct asymmetry. All calculations for the meta-analysis were performed using MIX 2.0. V.2.0.1.4. BiostatXL, 2011, available from http://www. meta-analysis-made-easy.com, Comprehensive Meta Analysis CMA, V.2.2.064, available from http://www. meta-analysis.com, and Microsoft Excel 2013.

\section{RESULTS}

The search resulted in 516 records. Of them, 297 study reports were removed as being duplicates, conference proceedings, posters, theses, etc. After including five reports found from the reference lists of identified review articles, 224 records were screened on the basis of their titles and abstracts. Of these records, full texts of 58 reports were screened more thoroughly, and 12 were considered relevant for qualitative analysis ${ }^{11-22}$ (details in figure 1). Similarity of outcome measures, needed for meta-analysis, was found among five different reports. ${ }^{11} 14$ 20-22 Additionally, two subgroups in the study by DiFrancisco-Donoghue $e a^{17}$ (one sample comparing PRT with usual care and another comparing PRT and vitamins with vitamins alone) were used in meta-analysis.

\section{Qualitative analysis of 12 included studies}

Table 1 shows the descriptive characteristics of included studies. Publication years varied from 1997 to 2014.

Eight studies were conducted in the USA and four in Australia. The size of the intervention groups at the end of follow-up varied from 6 to 22. Most of the studies only reported pretreatment/post-treatment results. Two of 12 studies also had a short 1 month follow-up after intervention. ${ }^{13}{ }^{19}$ In the samples, male gender predominated and the mean age of participants varied from 59 to 71 years. The implementation schemes of PRT varied widely across the studies. The progression of training load was usually defined by one repetition maximum, by participant's fatigue, or by achieving an agreed amount of repetitions. The duration of intervention varied from 1.5 to 24 months with a frequency of two or three times per week. Of 12 studies, 10 reported a positive effect of intervention. Six studies compared progressive resistance training with weakly defined 'usual activities', ${ }^{1-13}$ 16-18 four with different low-intensity strengthening, endurance or balance exercises, ${ }^{14151920}$ one with the use of vitamins, ${ }^{17}$ and one with treadmill training. ${ }^{22}$ It is selfevident that most of the patients with PD have more than one treatment. Thus, when comparing PRT and vitamins against only vitamins, omitting vitamins was accepted by us as approximation and the study by DiFrancisco-Donoghue et $a l^{17}$ could be included into this review. The outcome measures of included studies spread across a wide spectrum and are presented in online supplementary file 2 along with their reported main results.

The risk of bias was considered low for nine studies and high for three studies (table 2). The most frequent source of potential bias was the performance bias related to the inadequate or insufficiently reported blinding procedure.

The included studies reported positive effects of PRT on the score of the Freezing of Gait Questionnaire, ${ }^{11}$ oxidative stress, ${ }^{12}$ gait velocity and endurance, ${ }^{14}$ the scores of Parkinson's Disease Rating Scale and Modified Fitness Counts, ${ }^{15}$ cognitive functioning (demonstrating no effect on mood or disease-specific quality of life), ${ }^{16}$ gait initiation performance ${ }^{18}$ and muscle strength of trunk and/or lower extremities. ${ }^{13}$ 19-22 One study found PRT to be more effective at increasing glutathione levels and decreasing homocysteine levels compared with controls but without differences when compared with vitamin intake. ${ }^{17}$

\section{Meta-analyses of six included studies}

The risk of bias of all six studies was considered low. Five different meta-analyses were conducted on two to four samples sized from 6 to 22 participants each. When 


\begin{tabular}{|c|c|c|c|c|c|c|c|}
\hline \multirow[b]{2}{*}{ Study/year/country } & \multicolumn{2}{|c|}{$\begin{array}{l}\text { Cases/controls, } \\
\mathrm{N}(\% \text { men) }\end{array}$} & \multirow[b]{2}{*}{ Age * } & \multirow[b]{2}{*}{ Case treatment } & \multirow{2}{*}{$\begin{array}{l}\text { Intensity and } \\
\text { duration }\end{array}$} & \multirow[b]{2}{*}{ Control treatment } & \multirow{2}{*}{$\begin{array}{l}\text { Response to } \\
\text { treatment }\end{array}$} \\
\hline & Baseline & Follow-up & & & & & \\
\hline $\begin{array}{l}\text { Allen } \\
2010 \\
\text { Australia }\end{array}$ & $\begin{array}{l}24(54) / 24 \\
(54)\end{array}$ & $21 / 24$ & $66 / 68$ & $\begin{array}{l}\text { Progressive lower limb strengthening and } \\
\text { balance exercises (a monthly exercise } \\
\text { class, remaining exercise sessions at } \\
\text { home). Standardised falls prevention } \\
\text { advice (booklet) }\end{array}$ & $\begin{array}{l}40-60 \text { min } 3 \\
\text { times per week } \\
\text { for } 6 \text { months }\end{array}$ & $\begin{array}{l}\text { Usual care. Standardised } \\
\text { falls prevention advice } \\
\text { (booklet) }\end{array}$ & $\begin{array}{l}\text { Insignificant } \\
\text { difference }\end{array}$ \\
\hline $\begin{array}{l}\text { Bloomer } \\
2008 \\
\text { USA }\end{array}$ & $\begin{array}{l}8(50) / 8 \\
(50)\end{array}$ & $6 / 7$ & $61 / 57$ & $\begin{array}{l}\text { Three sets of } 5-8 \text { repetitions: leg press, leg } \\
\text { curl and calf press. Increased weight by } 5- \\
10 \% \text { when } 8 \text { repetitions were completed for } \\
\text { all } 3 \text { sets }\end{array}$ & $\begin{array}{l}\text { Two times per } \\
\text { week for } \\
2 \text { months }\end{array}$ & Usual activity & Positive \\
\hline $\begin{array}{l}\text { Bridgewater } \\
1997 \\
\text { Australia }\end{array}$ & $\begin{array}{l}13(69) / 13 \\
(54)\end{array}$ & $13 / 13$ & $67 / 66$ & $\begin{array}{l}15 \text { min warm-up. Trunk muscles (back } \\
\text { extensors and abdominals): } 10 \text { repetitions } \\
\text { of } 7 \mathrm{~s} \text { isometric contractions with } 7 \mathrm{~s} \text { rest. } \\
\text { Progression: as individual ability and } \\
\text { improvement allowed }\end{array}$ & $\begin{array}{l}\text { Two times per } \\
\text { week for } \\
3 \text { months }\end{array}$ & $\begin{array}{l}\text { Usual activity and 'interest } \\
\text { talks' on health issues } \\
\text { Once every } 3 \text { weeks }\end{array}$ & Positive \\
\hline $\begin{array}{l}\text { Combs } \\
2013 \\
\text { USA }\end{array}$ & $\begin{array}{l}17(65) / 14 \\
(71)\end{array}$ & $11 / 11$ & $67 / 68$ & $\begin{array}{l}15 \text { min warm-up. Boxing circuit, endurance. } \\
\text { Progression: self-progressed by completing } \\
\text { more repetitions during each training bout } \\
\text { as intensely as tolerated }\end{array}$ & $\begin{array}{l}24-36 \times 90 \mathrm{~min} \\
\text { for } 3 \text { months }\end{array}$ & $\begin{array}{l}\text { Strengthening, endurance } \\
\text { and balance exercises }\end{array}$ & Positive \\
\hline $\begin{array}{l}\text { Corcos } \\
2013 \\
\text { USA }\end{array}$ & $\begin{array}{l}24(58) / 24 \\
(58)\end{array}$ & $20 / 18$ & $59 / 59$ & $\begin{array}{l}\text { Strength: } 1-3 \text { sets of } 8 \times 6-9 \text { s repetitions; } \\
\text { speed: } 2 \text { sets of } 12 \text { repetitions. } \\
\text { Progression: } 5 \% \text { depending on one } \\
\text { repetition maximum }\end{array}$ & $\begin{array}{l}\text { Two times per } \\
\text { week for } \\
24 \text { months }\end{array}$ & $\begin{array}{l}\text { Stretches, balance } \\
\text { exercises, breathing and } \\
\text { non-progressive } \\
\text { strengthening }\end{array}$ & Positive \\
\hline $\begin{array}{l}\text { Cruise } \\
2011 \\
\text { Australia }\end{array}$ & $\begin{array}{l}15(60) / 13 \\
(69)\end{array}$ & $14 / 10$ & $59 / 61$ & $\begin{array}{l}5 \text { min warm-up (walking, stationary cycling } \\
\text { and stretching), } 6 \text { resistance exercises. } \\
\text { Progression: } 5-10 \% \text { based on one } \\
\text { repetition maximum. Aerobic component } \\
25-30 \text { min }\end{array}$ & $\begin{array}{l}60 \text { min } 2 \text { times } \\
\text { per week for } \\
3 \text { months }\end{array}$ & Usual activities & Positive \\
\hline $\begin{array}{l}\text { DiFrancisco-Donoghue } \\
2012 \\
\text { USA }\end{array}$ & $\begin{array}{l}10(77) / 9 \\
(33) \dagger \\
12(56) / 10 \\
(56) \ddagger\end{array}$ & $\begin{array}{l}9 / 9 \dagger \\
99 \ddagger\end{array}$ & $\begin{array}{l}68 / \\
68 \dagger \\
67 / \\
69 \ddagger\end{array}$ & $\begin{array}{l}20 \text { min aerobic exercise, weight training } 2 \\
\text { sets of } 8-15 \text { repetitions with } 30 \text { s rest } \\
\text { between. Progression: weight increased by } \\
5 \text { lbs when } 15 \text { repetitions per set were } \\
\text { achieved }\end{array}$ & $\begin{array}{l}40 \text { min } 2 \text { times } \\
\text { per week for } 1 \frac{1 / 2}{2} \\
\text { months }\end{array}$ & $\begin{array}{l}\text { Usual activities. } \\
\text { Vitamins: folic acid, } B_{12} \text { and } \\
B_{6}\end{array}$ & $\begin{array}{l}\text { Insignificant } \\
\text { difference }\end{array}$ \\
\hline $\begin{array}{l}\text { Hass } \\
2012 \\
\text { USA }\end{array}$ & $\begin{array}{l}9(77) / 9 \\
(77)\end{array}$ & $9 / 9$ & $64 / 67$ & $\begin{array}{l}5 \text { min warm-up, } 2 \text { sets of } 12-20 \text { repetitions } \\
\text { of six exercises, } 5 \text { min break between sets. } \\
\text { Progression based on one repetition } \\
\text { maximum }\end{array}$ & $\begin{array}{l}\text { Two times per } \\
\text { week for } 2 \frac{1}{2} \\
\text { months }\end{array}$ & Usual activities & Positive \\
\hline $\begin{array}{l}\text { Hirsch } \\
2003 \\
\text { USA }\end{array}$ & $6 / 9$ & $\begin{array}{l}6 / 7 \S \\
6 / 9 \rrbracket\end{array}$ & $71 / 76$ & $\begin{array}{l}\text { Balance+resistance training. Resistance } \\
\text { training: } 15 \text { min lower extremities, } 1 \text { set of } \\
12 \text { repetitions, and } 2 \text { min rest between }\end{array}$ & $\begin{array}{l}\text { Three times per } \\
\text { week for } 2 \frac{1}{2} \\
\text { months }\end{array}$ & Balance training & Positive \\
\hline
\end{tabular}




\begin{tabular}{|c|c|c|c|c|c|c|c|}
\hline \multirow[b]{2}{*}{ Study/year/country } & \multicolumn{2}{|c|}{$\begin{array}{l}\text { Cases/controls, } \\
\mathrm{N}(\% \text { men) }\end{array}$} & \multirow[b]{2}{*}{ Age * } & \multirow[b]{2}{*}{ Case treatment } & \multirow{2}{*}{$\begin{array}{l}\text { Intensity and } \\
\text { duration }\end{array}$} & \multirow[b]{2}{*}{ Control treatment } & \multirow{2}{*}{$\begin{array}{l}\text { Response to } \\
\text { treatment }\end{array}$} \\
\hline & Baseline & Follow-up & & & & & \\
\hline & & & & $\begin{array}{l}\text { exercises. Progression based on } 4 \\
\text { repetitions maximum }\end{array}$ & & & \\
\hline $\begin{array}{l}\text { Paul } \\
2014 \\
\text { Australia }\end{array}$ & $\begin{array}{l}20(65) / 20 \\
(60)\end{array}$ & $\begin{array}{l}18 / 18 \S 19 / \\
19^{\star \star}\end{array}$ & $68 / 65$ & $\begin{array}{l}\text { Three sets of } 8 \text { repetitions for } 4 \text { muscle } \\
\text { groups. Progression: increase by } 5 \% \text { when } \\
10 \text { repetitions achieved }\end{array}$ & $\begin{array}{l}45 \text { min } 2 \text { times } \\
\text { per week for } \\
3 \text { months }\end{array}$ & $\begin{array}{l}\text { Low intensity exercises for } \\
\text { the trunk, leg flexors, leg } \\
\text { extensors and hip } \\
\text { abductors }\end{array}$ & Positive \\
\hline $\begin{array}{l}\text { Schilling } \\
2010 \\
\text { USA }\end{array}$ & $9 / 9$ & $\begin{array}{l}8(63) / 7 \\
(57)\end{array}$ & $61 / 57$ & $\begin{array}{l}\text { Warm-up, } 3 \text { sets of } 5-8 \text { repetitions of the } \\
\text { leg press, leg curl and calf press. } \\
\text { Progression: when } 8 \text { repetitions for all } 3 \\
\text { sets were completed, the weight was } \\
\text { increased by } 5-10 \%\end{array}$ & $\begin{array}{l}\text { Two times per } \\
\text { week for } \\
2 \text { months }\end{array}$ & Standard care & Positive \\
\hline $\begin{array}{l}\text { Shulman } \\
2013 \\
\text { USA }\end{array}$ & $\begin{array}{l}28 † \dagger / \\
26 \neq \ddagger\end{array}$ & $\begin{array}{l}22(82) \dagger \dagger / \\
22(73) \neq \ddagger\end{array}$ & $\begin{array}{l}65 \dagger † / \\
66 \ddagger \ddagger\end{array}$ & $\begin{array}{l}\text { Resistance exercises: } 2 \text { sets of } 10 \\
\text { repetitions (leg press, leg extension and leg } \\
\text { curl). Progression: weight increased as } \\
\text { tolerated }\end{array}$ & $\begin{array}{l}\text { Three times per } \\
\text { week for } \\
3 \text { months }\end{array}$ & $\begin{array}{l}50 \text { min of lower intensity } \\
\text { treadmill }\end{array}$ & $\begin{array}{l}\text { Positive on } \\
\text { muscle } \\
\text { strength }\end{array}$ \\
\hline \multicolumn{8}{|c|}{$\begin{array}{l}\text { *Years in means. } \\
\text { †Training versus controls. } \\
\text { †Training and vitamins versus vitamins. } \\
\text { §Strength. } \\
\text { ๆBalance. } \\
\text { **Mobility and balance. } \\
\text { ††Stretching and Resistance Training. } \\
\text { ftLower-Intensity treadmill training (highe }\end{array}$} \\
\hline
\end{tabular}


Table 2 Risk of bias of included studies

\begin{tabular}{|c|c|c|c|c|c|c|c|c|}
\hline Study & $\begin{array}{l}\text { Random } \\
\text { sequence } \\
\text { generation }\end{array}$ & $\begin{array}{l}\text { Allocation } \\
\text { concealment }\end{array}$ & $\begin{array}{l}\text { Blinding of } \\
\text { participants } \\
\text { and } \\
\text { personnel }\end{array}$ & $\begin{array}{l}\text { Blinding of } \\
\text { outcome } \\
\text { assessment }\end{array}$ & $\begin{array}{l}\text { Incomplete } \\
\text { outcome } \\
\text { data }\end{array}$ & $\begin{array}{l}\text { Selective } \\
\text { reporting }\end{array}$ & $\begin{array}{l}\text { Other } \\
\text { sources } \\
\text { of bias }\end{array}$ & $\begin{array}{l}\text { Total } \\
\text { risk } \\
\text { of } \\
\text { bias }\end{array}$ \\
\hline Allen et al ${ }^{11}$ & Low & Low & High & Low & Low & Low & Low & Low \\
\hline Bloomer et al ${ }^{12}$ & Low & Unclear & High & Low & Low & Low & Low & Low \\
\hline Bridgewater et al ${ }^{13}$ & High & Unclear & High & High & Low & Low & Low & High \\
\hline Combs et al $1^{14}$ & Low & Low & High & Low & Low & Low & Low & Low \\
\hline Corcos et al ${ }^{15}$ & Low & Low & High & Low & Low & Low & Low & Low \\
\hline Cruise et $a l^{16}$ & High & Unclear & High & High & Low & Low & Low & High \\
\hline $\begin{array}{l}\text { DiFrancisco-Donoghue } \\
\text { et al } 1^{17}\end{array}$ & Low & Unclear & High & High & Low & Low & Low & Low \\
\hline Hass et $a l^{18}$ & Low & Unclear & High & High & Low & Low & Low & Low \\
\hline Hirsch et al ${ }^{19}$ & High & Unclear & High & High & Low & Low & Low & High \\
\hline Paul et $a^{R o}$ & Low & Unclear & High & Low & Low & Low & Low & Low \\
\hline Schilling et $a^{P^{1}}$ & Low & Unclear & High & High & Low & Low & Low & Low \\
\hline Shulman et $a^{{ }^{2}}$ & Low & Low & Low & Low & Low & Low & Low & Low \\
\hline
\end{tabular}

appropriate, measurement units were converted into metric units. Table 3 and online supplementary figures $3 \mathrm{~A}-\mathrm{E}$ present the input data and the results of all five syntheses.

The effect of PRT on fast walking speed was assessed by pooling samples of three studies. ${ }^{112022}$ The pooled sample consisted of 49 cases versus 55 controls. The pooled effect size was $0.06 \mathrm{~ms}(95 \%$ CI 0.02 to 0.11$)$ in favour of intervention, but below the minimal detectable change of $0.25 \mathrm{~ms}$ as suggested previously. ${ }^{23}$ The $\mathrm{I}^{2}$ was $61 \%$, indicating substantial heterogeneity.

The effect of PRT on comfortable walking speed was assessed by pooling samples of four studies. $11 \quad 142022$ The pooled sample consisted of 60 cases versus 66 controls. The pooled effect size was $0.03 \mathrm{~ms}(95 \%$ CI 0.01 to 0.05 ) in favour of intervention, but below the minimal detectable change of $0.18 \mathrm{~ms}$ as suggested previously. ${ }^{23}$ The $\mathrm{I}^{2}$ was $15 \%$, indicating insignificant heterogeneity.

The effect of PRT on Timed Up and Go test was assessed by pooling samples of three studies. ${ }^{142021}$ The size of pooled sample was 26 cases versus 29 controls. The pooled effect size was statistically insignificant $-0.71 \mathrm{~s}(95 \% \mathrm{CI}-1.47$ to 0.06$)$ in favour of intervention and below the minimal detectable change of $3.5 \mathrm{~s}$ as suggested previously. ${ }^{24}$ The $\mathrm{I}^{2}$ was $0 \%$, indicating insignificant heterogeneity.

The effect of PRT on the 6 min walk test was assessed by pooling samples of three studies. ${ }^{142122}$ The pooled sample was 42 cases versus 42 controls. The pooled effect size was $16.67 \mathrm{~m}$ (95\% CI 7.86 to 25.48$)$ in favour of intervention, but below the minimal detectable change of $82 \mathrm{~m}$ as suggested previously. ${ }^{23}$ The $\mathrm{I}^{2}$ was $47 \%$, indicating moderate heterogeneity.

The effect of PRT on maximal oxygen consumption was assessed by pooling samples of two studies $^{17} 22$ including three samples: two different samples from the study by DiFrancisco-Donoghue et al and one sample from the study by Shulman et al. The pooled sample was
40 cases versus 40 controls. The pooled effect size was $-1.6 \mathrm{~mL} / \mathrm{kg} / \mathrm{min}(95 \% \mathrm{CI}-1.93$ to -1.27$)$ in favour of intervention and below the minimal clinically significant difference of $2 \mathrm{~mL} / \mathrm{kg} / \mathrm{min}$ as suggested previously. ${ }^{25}$ The $\mathrm{I}^{2}$ was $85 \%$, indicating substantial heterogeneity.

The Egger's test for asymmetry of the funnel plot did not reveal a potential publication bias in any of the syntheses.

\section{DISCUSSION}

In this systematic review of 12 RCTs, no evidence was found on the superiority of PRT in the rehabilitation of people with idiopathic Parkinson's disease when compared to other training or to usual activities. Few studies conducted on small sample sizes with short periods of follow-up reported some positive effects of PRT on freezing symptoms, gait, cognitive performance and muscle strength. Meta-analyses of these studies did not find clinically significant effects of PRT on walking speed, walking distance, Timed Up and Go test or aerobic performance.

The case and control treatments, as well as intensity, duration and frequency of PRT, employed in the selected studies were diverse and sometimes hardly comparable. The included studies have been conducted on relatively small samples and the effects were followed up for only a few months at most. In this review, a 'small number of repetitions' was defined according to the classic work of DeLorme and Watkins in $1948 .^{2}$ The use of a more precise definition given by the American College of Sports Medicine, defining a 'small number of repetitions' as $\leq 12$ repetitions, might alter our results. ${ }^{26}$ Owing to the uncertain definition of PRT, it is possible that some relevant studies remained undetected. However, we used very wide search clauses and performed the rest of the search and selection manually in order to avoid missing the potentially relevant reports. 


\begin{tabular}{|c|c|c|c|c|c|c|c|c|c|c|c|}
\hline \multirow[b]{2}{*}{ Outcome (units), study } & \multicolumn{3}{|c|}{ Cases, mean (SD) } & \multicolumn{3}{|c|}{ Controls, mean (SD) } & \multicolumn{2}{|l|}{ Effect size } & \multirow[b]{2}{*}{$I^{2}(\%)$} & \multicolumn{2}{|c|}{ Egger's regression } \\
\hline & Baseline & Follow-up & $\mathbf{N}$ & Baseline & Follow-up & $\mathbf{N}$ & $\begin{array}{l}\text { Raw mean } \\
\text { difference }\end{array}$ & $95 \% \mathrm{Cl}$ & & Intercept & $95 \% \mathrm{Cl}$ \\
\hline \multicolumn{7}{|l|}{ Fast walking speed (ms) } & 0.06 & 0.02 to 0.11 & 61 & -3.27 & -69.0 to 62.4 \\
\hline Allen et $a l^{11}$ & $1.47(0.38)$ & $1.61(0.35)$ & 21 & $1.54(0.35)$ & $1.48(0.43)$ & 24 & 0.2 & -0.001 to 0.40 & & & \\
\hline Paul et $a^{\text {Po }}$ & - & $0.02(0.16)^{\star}$ & 6 & - & $0.01(0.19)^{\star}$ & 9 & 0.01 & -0.18 to 0.2 & & & \\
\hline Shulman et $a^{R^{2}} \dagger$ & $0.84(0.05)$ & $0.84(0.05)$ & 22 & $0.85(0.05)$ & $0.79(0.05)$ & 22 & 0.06 & 0.03 to 0.09 & & & \\
\hline \multicolumn{7}{|c|}{ Comfortable walking speed (ms) } & 0.03 & 0.01 to 0.05 & 15 & -1.34 & -13.8 to 11.2 \\
\hline Allen et $a l^{11}$ & $1.07(0.27)$ & $1.09(0.26)$ & 21 & $1.04(0.25)$ & $1.06(0.32)$ & 24 & 0.0 & -0.15 to 0.15 & & & \\
\hline Combs et $\mathrm{al}^{14}$ & $1.06(1.08)$ & $1.10(1.10)$ & 11 & $1.15(0.72)$ & $1.22(0.64)$ & 11 & 0.03 & -0.65 to 0.71 & & & \\
\hline Paul et afo & - & $0.06(0.16)^{\star}$ & 6 & - & $0.05(0.12)^{*}$ & 9 & 0.01 & -0.13 to 0.15 & & & \\
\hline Shulman et $a^{R^{2}} \ddagger$ & $0.72(0.05)$ & $0.71(0.05)$ & 22 & $0.73(0.04)$ & $0.69(0.04)$ & 22 & 0.03 & 0.01 to 0.05 & & & \\
\hline \multicolumn{7}{|c|}{ Timed Up and Go Test (s) } & -0.71 & -1.47 to 0.06 & 0 & -5.28 & -61.1 to 50.5 \\
\hline Combs et $a l^{14}$ & 8.05 (15.12) & $7.12(14.62)$ & 11 & $7.64(7.39)$ & $7.12(5.47)$ & 11 & -0.41 & -9.04 to 8.22 & & & \\
\hline Paul et a PO $^{20}$ & - & $-1.3(2.7)^{\star}$ & 6 & - & $-0.1(2.0)^{\star}$ & 9 & -1.2 & -3.57 to 1.17 & & & \\
\hline Schilling et $a$ R1 $^{1}$ & $5.8(0.50)$ & $5.7(0.80)$ & 9 & $7.5(1.18)$ & $6.75(1.21)$ & 9 & -0.65 & -0.47 to 0.06 & & & \\
\hline \multicolumn{7}{|l|}{6 min walk $(\mathrm{m})$} & 16.67 & 7.86 to 25.48 & 47 & -6.14 & -42.8 to 30.5 \\
\hline Combs et $a 1^{14}$ & $\begin{array}{l}405.0 \\
(549.1)\end{array}$ & $457.0(669.7)$ & 11 & $\begin{array}{l}484.4 \\
(301.2)\end{array}$ & $478.7(183.9)$ & 11 & 57.7 & -300.21 to 415.6 & & & \\
\hline Schilling et $a^{R^{1}}$ & $537.7(88.1)$ & $586.9(51.0)$ & 9 & 468.8 (83.3) & $493.9(64.3)$ & 9 & 24.1 & -39.97 to 88.17 & & & \\
\hline Shulman et $a^{R^{2}} \S$ & - & $32.6(14.6)^{\star}$ & 22 & - & $49.1(15.5)^{\star}$ & 22 & 16.5 & 7.86 to 25.48 & & & \\
\hline \multicolumn{7}{|c|}{ Maximal oxygen consumption (mL/kg/min) } & -1.6 & -1.93 to -1.27 & 85 & 26.18 & -103.5 to 155.9 \\
\hline $\begin{array}{l}\text { DiFrancisco-Donoghue } \\
\text { et } a l^{17} \emptyset\end{array}$ & $13.3(2.7)$ & $11.6(2.4)$ & 9 & $13.0(2.8)$ & $12.8(2.9)$ & 9 & -1.5 & -3.74 to 0.74 & & & \\
\hline $\begin{array}{l}\text { DiFrancisco-Donoghue } \\
\text { et }\left.a\right|^{17 \star}\end{array}$ & $11.5(2.1)$ & $10.0(2.0)$ & 9 & $13.9(2.8)$ & $14.6(2.6)$ & 9 & -2.2 & -4.19 to -0.22 & & & \\
\hline Shulman et $a^{22}$ & - & $-0.052(0.4) *$ & 22 & - & $1.53(0.7)^{*}$ & 22 & -1.6 & -1.93 to -1.25 & & & \\
\hline \multicolumn{12}{|c|}{$\begin{array}{l}{ }^{*} \text { Change from baseline for each group. } \\
\text { †Converted from seconds ( } 50 \text { feet distance) to } \mathrm{ms} \text {. } \\
\text { †Converted from seconds ( } 10 \mathrm{~m} \text { distance) to } \mathrm{ms} \text {. } \\
\text { §Converted from feet to metres. } \\
\text { १्Exercise versus controls. }\end{array}$} \\
\hline
\end{tabular}


The data from the included records were extracted by one researcher, which might affect the objectivity of the process, even if the data extracted were presented to all the authors for the discussion and approved.

When compared to recent systematic reviews on the topic, we identified considerably more relevant studies. The reason for being able to identify more relevant reports than previous reviews on the topic did was probably the fact that the search we performed used very few limits, relying on the manual (though time-consuming) fine-tuning of initial search results. Our results are in line with a recent review by Brienesse et a $a \tilde{l}$ which reported lack of evidence on the effectiveness of PRT. We ended up, however, with a more robust conclusion that, based on several small-sample good-quality RCTs, there is limited evidence on PRT being no more effective in Parkinson's disease than other physical training schemes. In contrast to our finding, a review by Lima et at suggested that "progressive resistance training should be implemented in Parkinson's disease rehabilitation" and a review by David $e t a l^{7}$ concluded that "...there is a strong rationale for the use of PRE [progressive resistance exercise] as an adjunct treatment in PD [Parkinson's disease] ..." Such strong recommendations cannot be supported by our results. Since there is no evidence on the superiority or better safeness of one specific training scheme over another in patients with PD, rehabilitation providers may include or avoid PRT depending on the settled practice and costs of a particular rehabilitation programme.

In our review, the risk of bias was considered low in 9 of 12 studies. Problems, however, arise from other than methodological issues covered by the scale we used. It is likely that the included studies had insufficient statistical power, undetermined clinical significance and mostly insufficiently described treatment in control groups. They also differed in the degree of disease severity. Implemented schemes of PRT varied from weightlifting to boxing exercises. Even if a study was methodologically well planned and executed, the level of statistical significance is rarely achieved in small samples. Only very large treatment effect sizes could be detected in trials with 20 or less participants. Additionally, statistically significant results, if observed, may not exceed the level of clinical significance, and this should also be taken into account when making clinical recommendations. For example, our meta-analyses on fast and comfortable walking speed and maximal oxygen consumption showed statistical but not clinical significance of pooled effect sizes. The statistically significant pooled effect size observed in meta-analysis on the 6 min walk test fell below the level of minimal detectable change for this test. Unexpectedly, none of the trials followed the effects of PRT for more than 1 month after the end of a supervised training programme. It has been reported previously that the beneficial effects of training may persist for several months after the cessation of training. ${ }^{27}$

The most common source of potential systematic bias in the selected studies was the lack of blinding of participants and personnel. This source of bias is hardly avoidable when physical therapy is involved as the involvement is based on the close participation of the patient and the therapist in the entire chain of planning, performing and assessing the intervention. While it is barely preventable, it could be statistically controlled, for example, by using repeated measures of expectancy and beliefs about the demands of the research throughout the trial. ${ }^{28}$

The search was a year old at the time of accepting this review for publication. Thus, the additional verifying search was conducted on Pubmed seeking relevant papers published between April 2014 and October 2015 and using the same clauses as did previous search. Only one potentially relevant trial was identified. That RCT by Prodoehl $e t a t^{29}$ compared the effects of progressive resistance exercises and a modified Fitness Counts program on the physical function of people with moderate PD. That study used the subset of data used previously in the paper by Corcos et al included in our analysis. The main outcome used by Prodoehl et al included a Modified Physical Performance Test, five times sit to stand test, Functional Reach Test, Timed Up and Go, Berg Balance Scale, 6 min walk test and 50 feet walking speed. In a 2-year follow-up, both groups showed improvements across all studied outcome measures, except for the 6 min walk test without significant differences between treatment methods. It is reasonable to assume that the findings of that trial would not affect our main results.

To make definite clinical recommendations possible, further research should focus on randomised trials on larger sample sizes and with sufficient follow-up periods after the end of the intervention. The safety of PRT in a target population should also be evaluated in comparison with other types of physical training. Further studies may also reveal the effects of resistance training on such important outcome measures as quality of life, activities of daily living, cost-effectiveness, and muscle strength, which are left out of the scope of this review.

\section{Conclusions}

Even if physical training is important for health and functioning, there is so far no evidence on the superiority of progressive resistance training compared with other treatments to support the use of this technique in rehabilitation of idiopathic Parkinson's disease. There is limited evidence on progressive resistance training being ineffective in Parkinson's disease compared with other physical training schemes.

\footnotetext{
Author affiliations

${ }^{1}$ Department of Physical and Rehabilitation Medicine, Turku University Hospital and University of Turku, Turku, Finland

${ }^{2}$ Satakunta University of Applied Sciences, Pori, Finland

${ }^{3}$ School of Health and Social Studies, JAMK University of Applied Sciences, Jyväskylä, Finland

${ }^{4}$ Turku University of Applied Sciences, Turku, Finland
} 
Contributors MS, EB, JP, NK and KL substantially contributed to the conception and design of the work and the acquisition and interpretation of data. MS was responsible for the meta-analytic calculations. MS drafted the work and EB, JP, NK and KL revised the draft and approved the version to be submitted and published. KL was a senior investigator and guarantor. MS, $E B, J P, N K$ and $K L$ agreed on all aspects of the work related to the accuracy or integrity of all parts of the work.

Funding This research received no specific grant from any funding agency in the public, commercial or not-for-profit sectors.

Competing interests None declared.

Provenance and peer review Not commissioned; externally peer reviewed.

Data sharing statement No additional data are available.

Open Access This is an Open Access article distributed in accordance with the Creative Commons Attribution Non Commercial (CC BY-NC 4.0) license, which permits others to distribute, remix, adapt, build upon this work noncommercially, and license their derivative works on different terms, provided the original work is properly cited and the use is non-commercial. See: http:// creativecommons.org/licenses/by-nc/4.0/

\section{REFERENCES}

1. Delorme TL. Restoration of muscle power by heavy-resistance exercises. J Bone Joint Surg Am 1945;27:645-67.

2. Delorme TL, Watkins AL. Technics of progressive resistance exercise. Arch Phys Med Rehabil 1948;29:263-73.

3. Taylor NF, Dodd KJ, Damiano DL. Progressive resistance exercise in physical therapy: a summary of systematic reviews. Phys Ther 2005;85:1208-23.

4. Valenzuela T. Efficacy of progressive resistance training interventions in older adults in nursing homes: a systematic review. J Am Med Dir Assoc 2012;13:418-28.

5. Brienesse LA, Emerson MN. Effects of resistance training for people with Parkinson's disease: a systematic review. J Am Med Dir Assoc 2013;14:236-41.

6. Lima LO, Scianni A, Rodrigues-de-Paula F. Progressive resistance exercise improves strength and physical performance in people with mild to moderate Parkinson's disease: a systematic review. $J$ Physiother 2013;59:7-13.

7. David FJ, Rafferty MR, Robichaud JA, et al. Progressive resistance exercise and Parkinson's disease: a review of potential mechanisms. Parkinsons Dis 2012;2012:124527.

8. Falvo MJ, Schilling BK, Earhart GM. Parkinson's disease and resistive exercise: rationale, review, and recommendations. Mov Disord 2008;23:1-11.

9. Higgins J, Green S. Cochrane Handbook for Systematic Reviews of Interventions Version 5.1.0 [updated March 2011], 2011. Chapter 7.7. http://handbook.cochrane.org (accessed 4 Jan 2016).

10. Higgins J, Green S. Cochrane Handbook for Systematic Reviews of Interventions Version 5.1.0 [updated March 2011], 2011, Chapter 8.5. http://handbook.cochrane.org (accessed 4 Jan 2016).

11. Allen NE, Canning CG, Sherrington C, et al. The effects of an exercise program on fall risk factors in people with Parkinson's disease: a randomized controlled trial. Mov Disord 2010;25:1217-25.

12. Bloomer RJ, Schilling BK, Karlage RE, et al. Effect of resistance training on blood oxidative stress in Parkinson disease. Med Sci Sports Exerc 2008;40:1385-9. http://onlinelibrary.wiley.com/o/
cochrane/clcentral/articles/087/CN-00666087/frame.html http:// graphics.tx.ovid.com/ovftpdfs/FPDDNCLBGELFHP00/fs046/ovft/live/ gv023/00005768/00005768-200808000-00006.pdf

13. Bridgewater $\mathrm{KJ}$, Sharpe $\mathrm{MH}$. Trunk muscle training and early Parkinson's disease. Physiother Theory Pract 1997;13:139-53.

14. Combs SA, Diehl MD, Chrzastowski C, et al. Community-based group exercise for persons with Parkinson disease: a randomized controlled trial. NeuroRehabilitation 2013;32:117-24. http:// onlinelibrary.wiley.com/o/cochrane/clcentral/articles/293/ CN-00965293/frame.html http://iospress.metapress.com/content v8275k42727tv6h0/?genre=article\&issn=1053-8135\&volume $=32 \&$ issue $=1 \&$ spage $=117$

15. Corcos DM, Robichaud JA, David FJ, et al. A two-year randomized controlled trial of progressive resistance exercise for Parkinson's disease. Mov Disord 2013;28:1230-40.

16. Cruise KE, Bucks RS, Loftus AM, et al. Exercise and Parkinson's: benefits for cognition and quality of life. Acta Neurol Scand 2011;123:13-19.

17. DiFrancisco-Donoghue J, Lamberg EM, Rabin E, et al. Effects of exercise and $B$ vitamins on homocysteine and glutathione in Parkinson's disease: a randomized trial. Neurodegener Dis 2012;10:127-34.

18. Hass CJ, Buckley TA, Pitsikoulis C, et al. Progressive resistance training improves gait initiation in individuals with Parkinson's disease. Gait Posture 2012;35:669-73.

19. Hirsch MA, Toole T, Maitland CG, et al. The effects of balance training and high-intensity resistance training on persons with idiopathic Parkinson's disease. Arch Phys Med Rehabil 2003;84:1109-17.

20. Paul SS, Canning CG, Song J, et al. Leg muscle power is enhanced by training in people with Parkinson's disease: a randomized controlled trial [with consumer summary]. Clin Rehabil 2014;28:275-88.

21. Schilling BK, Pfeiffer RF, Ledoux MS, et al. Effects of moderate-volume, high-load lower-body resistance training on strength and function in persons with Parkinson's disease: a pilot study. Parkinsons Dis 2010;2010:824734.

22. Shulman LM, Katzel LI, Ivey FM, et al. Randomized clinical trial of 3 types of physical exercise for patients with Parkinson disease. JAMA Neurol 2013;70:183-90.

23. Steffen T, Seney M. Test-retest reliability and minimal detectable change on balance and ambulation tests, the 36-item short-form health survey, and the unified Parkinson disease rating scale in people with parkinsonism. Phys Ther 2008;88:733-46.

24. Huang S-L, Hsieh C-L, Wu R-M, et al. Minimal detectable change of the timed "up \& go" test and the dynamic gait index in people with Parkinson disease. Phys Ther 2011;91:114-21.

25. Kothmann E, Batterham AM, Owen SJ, et al. Effect of short-term exercise training on aerobic fitness in patients with abdominal aortic aneurysms: a pilot study. Br J Anaesth 2009;103:505-10.

26. American College of Sports M. American College of Sports Medicine position stand. Progression models in resistance training for healthy adults. Med Sci Sports Exerc 2009;41:687-708.

27. Ellis T, de Goede CJ, Feldman RG, et al. Efficacy of a physical therapy program in patients with Parkinson's disease: a randomized controlled trial. Arch Phys Med Rehabil 2005;86:626-32.

28. Button KS, Munafò MR. Addressing risk of bias in trials of cognitive behavioral therapy. Shanghai Arch Psychiatry 2015;27:144-8.

29. Prodoehl J, Rafferty MR, David FJ, et al. Two-year exercise program improves physical function in Parkinson's disease: the PRET-PD randomized clinical trial. Neurorehabil Neural Repair 2015;29:112-22. 